\title{
Lifetime risk and characterization of red blood cell alloimmunization in chronically transfused patients with sickle cell disease
}

\author{
Woldie I., Swerdlow P., Bluth M.H., Mohammad U., Landolfi E., \\ Chaudrhy S., Dyson G., O’ Malley B.A.
}

\begin{abstract}
Aims: Patients with sickle cell disease (SCD) are often exposed to multiple units of blood transfusions predisposing them to the development of alloantibodies. Alloantibodies make subsequent transfusion difficult, costly and could also result in life-threatening hemolysis. The aim of this study is to estimate and characterize alloantibodies developing over a life-time in patients with sickle cell disease who are on chronic red cell transfusion. Methods: Retrospective data were obtained from the electronic medical record and sunquest transfusion record of the DMC for a total of 121 patients with SCD aged 18 years and older who were on chronic red cell exchange transfusion. Data on demographics, blood group, genotype, total number of units transfused over lifetime, presence and type of alloantibodies identified was collected and analyzed. Results: The median age of the studied patients was 33 years with a male to female ratio of 0.73 . Almost all (>95\%) patients had homozygous SCD. A total of 67,586 units were transfused for the 121 patients over a lifetime approximating an average of 559 units transfused per patient. Alloantibodies were identified in 68 of the 121 patients $(56.2 \%)$. The most common antibody identified was $E$ (27\%)
\end{abstract}

Woldie I. ${ }^{1}$, Swerdlow P. ${ }^{1}$, Bluth M.H. ${ }^{2}$, Mohammad U. ${ }^{3}$, Landolfi E. ${ }^{2}$, Chaudrhy S. ${ }^{3}$, Dyson G. ${ }^{1}$, O' Malley B.A. $^{2}$

Affiliations: ${ }^{1}$ Department of Oncology, Wayne State University; ${ }^{2}$ Department of Pathology, Detroit Medical Center (DMC); ${ }^{3}$ Department of Internal Medicine, Detroit Medical Center.

Corresponding Author: Indryas Woldie, 4100 John R \# HW04H0, Detroit MI 48201; Tel: 313576 8022, Fax No: 313 576 8767; Email: woldiei@karmanos.org

Received: 07 October 2014

Accepted: 08 January 2015

Published: 27 February 2015 followed by $K$ (23\%) and C (12\%). Overall, antibodies against the $\mathrm{Rh}$ system (E, C, D and e) accounted for $39 \%$ of the identified antibodies. Conclusion: These data demonstrate a high lifetime rate of alloimmunization for patients with SCD on chronic red cell exchange transfusion. Understanding the nature of alloantibody development in chronically transfused SCD patients can help foster appropriate blood utilization paradigms, and develop preventive strategies.

Keywords: Alloimmunization, Chronic transfusion, Red blood cell, Sickle cell disease, Tranfusion

\section{How to cite this article}

Woldie I., Swerdlow P., Bluth M.H., Mohammad U., Landolfi E., Chaudrhy S., Dyson G., O’ Malley B.A. Lifetime risk and characterization of red blood cell alloimmunization in chronically transfused patients with sickle cell disease. Int $\mathrm{J}$ Blood Transfus Immunohematol 2015;5:1-5.

Article ID: 100015IJBTIWI2015

$$
* * * * * * * * *
$$

doi:10.5348/ijbti-2015-15-OA-1

\section{INTRODUCTION}

Patients with sickle cell disease (SCD) are often exposed to multiple units of blood transfusions throughout their lifetime which predisposes them to various complications, one of which is development of alloantibodies. Once a patient is found to have antibody 
against a red cell antigen, those antibodies are respected in subsequent transfusions to provide antigen negative units. Such newly identified alloantibodies make subsequent transfusion difficult, costly and could also result in life-threatening acute and delayed hemolytic transfusion reactions [1].

The risk of developing alloantibodies in patients with sickle cell disease is widely variable and estimated to range between $2.6-76 \%$ depending on the clinical characteristics of patients studied and the sensitivity of the tests used. Another estimate from a study showed $18-47 \%[1,2]$.

Various contributing factors have been suggested for higher rate of alloimmunization in patients with SCD compared to other patients. These include ethnic and racial differences between donor and recipient resulting in mismatched antigen exposure, increased inflammation and suppressed peripheral $\mathrm{T}$ cell regulatory function [24]. Although transfusion of phenotypically matched units was shown to reduce risk of alloimmunization, studies have showed significant alloimmunization despite use of phenotypically as well as racially matched units $[5,6]$.

Thus, understanding the lifetime risks of alloantibody generation in patients with SCD may help develop preventive strategies and help resource allocation for future research and patient management.

\section{MATERIALS AND METHODS}

\section{Study Design and Methods}

After obtaining appropriate ethical clearance, retrospective data was obtained from the electronic medical record (EMR) and sunquest transfusion record of the DMC. A total of 121 patients with sickle cell disease (SCD) aged 18 years older who were on chronic red cell exchange transfusion mostly for history of stroke were studied. Data pertaining to patient demographics, age at first transfusion, blood group, genotype, total number of units transfused over lifetime, as well as presence and type of alloantibodies identified was collected. The Sunquest transfusion record at the DMC incorporates all records of transfused units and alloantibodies identified from the time patient was first transfused at the DMC (including records transferred from the Children's Hospital of Michigan) to the time of data collection.

Transfusion practice is based on phenotypicallymatched leukoreduced RBC-units for ABO and Rh. Once patient is found to have antibody, those antibodies are respected in subsequent transfusions with extended phenotyping to include additional antigens in some cases. New patients are often transfused CEK negative units by order of the transfusing physician.

Statistical methods: Descriptive statistics were used to summarize data. Associations for categorical variables were made using chi-square test, while associations for continuous variables were tested using T-test.

\section{RESULTS}

The median age of study subjects was 33 years with a male to female ratio of 0.73 . Around $95 \%$ of the patients have homozygous sickle cell anemia (Hb-SS) disease and the rest have hemoglobin SC disease (Hb-SC). A total of 67,586 units were transfused for the 121 patients over a life-time thus approximating an average of 559 units transfused per patient. The median number of transfused units was 436 (minimum 14, maximum of 1774 units per patient) (Table 1).

Alloantibodies were identified in 68 of the 121 patients (56.2\%). Of the 68 patients with alloantibodies, 39 patients (57\%) had two or more antibodies. The most common antibody identified was E (27\%) followed by K (23\%) and C (12\%). Other identified alloantibodies (in descending order of frequency) included Fya and S; D; $\mathrm{Jkb}$ and LeA; Jsa and V; Cw; Kpa, M, hr-b, Goa and I; Cob, Wa, e, Wra, LeB. Overall, a total of 166 different red cell antibodies were identified in 68 patients with a mean of 2.4 antibodies per patient. Antibodies against the $\mathrm{Rh}$ system (E, C, D and e) accounted for 39\% of the identified antibodies (Table 2 and Table 3).

Table 1: Characteristics of patients on chronic red cell exchange $(\mathrm{n}=121)$

\begin{tabular}{|c|c|c|}
\hline Variable & Levels & $\mathbf{N}(\%)$ \\
\hline Median age & 33 years & \\
\hline Total units transfused & 67,586 & \\
\hline Median units transfused per patient & $\begin{array}{c}559 \\
(14-1774)\end{array}$ & \\
\hline Median units per exchange & $\begin{array}{c}6 \\
(3-9)\end{array}$ & \\
\hline \multicolumn{3}{|l|}{ Gender } \\
\hline & $\mathrm{F}$ & $70(0.58)$ \\
\hline & M & $51(0.42)$ \\
\hline \multicolumn{3}{|l|}{ Genotype } \\
\hline & SS & $115(0.95)$ \\
\hline & $\mathrm{SC}$ & $6(0.05)$ \\
\hline \multicolumn{3}{|l|}{ Alloantibody } \\
\hline & Yes & $68(56.2)$ \\
\hline & No & $53(43.8)$ \\
\hline \multicolumn{3}{|l|}{$\mathrm{Rh}$} \\
\hline & Negative & $12(0.10)$ \\
\hline & Positive & $109(0.90)$ \\
\hline \multicolumn{3}{|l|}{$\mathrm{ABO} / \mathrm{Rh}$} \\
\hline & A Negative & $5(0.04)$ \\
\hline & A Positive & $34(0.28)$ \\
\hline & AB Positive & 4(0.03) \\
\hline & B Negative & $3(0.02)$ \\
\hline & B Positive & $14(0.12)$ \\
\hline & O Negative & 4(0.03) \\
\hline & O Positive & $57(0.47)$ \\
\hline
\end{tabular}


Table 2: Frequency of antibodies identified in patients on chronic red cell exchange transfusion

\begin{tabular}{|c|c|c|}
\hline Antibodies & Number & Percentage \\
\hline $\mathrm{E}$ & 45 & 27.1 \\
\hline K & 38 & 23 \\
\hline C & 20 & 12.1 \\
\hline Fya & 9 & 5.4 \\
\hline S & 9 & 5.4 \\
\hline $\mathrm{D}$ & 6 & 3.6 \\
\hline JkB & 5 & 3 \\
\hline LeA & 5 & 3 \\
\hline Jsa & 4 & 2.4 \\
\hline V & 4 & 2.4 \\
\hline $\mathrm{Cw}$ & 3 & 1.8 \\
\hline JkA & 2 & 1.2 \\
\hline Goa & 2 & 1.2 \\
\hline I & 2 & 1.2 \\
\hline hr-b & 2 & 1.2 \\
\hline M & 2 & 1.2 \\
\hline Кра & 2 & 1.2 \\
\hline $\mathrm{Wa}$ & 1 & 0.6 \\
\hline LeB & 1 & 0.6 \\
\hline Cob & 1 & 0.6 \\
\hline Dia & 1 & 0.6 \\
\hline e & 1 & 0.6 \\
\hline Wra & 1 & 0.6 \\
\hline Total & 166 & 100 \\
\hline
\end{tabular}

\section{DISCUSSION}

The study showed high prevalence of alloantibody development (56.2\%) in patients with sickle cell disease who are on chronic red cell exchange transfusion. One explanation could be the methodology in this study which includes lifetime risk of alloantibodies through records that date back to their childhood until date of data collection. Although data is limited on patients who are on red cell exchange, the prevalence is still within the range identified for patients with sickle cell disease which was reported to be anywhere between $2.6-60 \%$ [1].

The rate is also much higher compared to a pediatric study that showed $24 \%$ of the patients on chronic red exchange developed alloantibodies. In addition to the age difference between the two studies, this study covered a lifetime prevalence of alloantibodies compared to the pediatric study which covers around four years [7].

None of the variables including; gender, age, number of transfused units and blood group was found to be significantly associated with development of alloantibodies in this study (Table 4). This is in contrast to a study by Chou et al. which showed higher
Table 3: List of antibodies identified in 68 patients on chronic red cell transfusion

\begin{tabular}{|c|c|}
\hline Antibodies & Antibodies \\
\hline C, E, K, S, Fya & $\mathrm{E}$ \\
\hline $\mathrm{E}$ & C, E, K \\
\hline E, LeA & C, E, K, JkA \\
\hline K & $\mathrm{E}$ \\
\hline $\mathrm{E}, \mathrm{K}, \mathrm{C}, \mathrm{JkB}$, Goa, S, Cw & $\mathrm{D}$ \\
\hline $\mathrm{E}, \mathrm{C}$ & C, E, Fya, Jka \\
\hline $\mathrm{D}$ & $\mathrm{K}$ \\
\hline $\mathrm{K}, \mathrm{Cw}$ & $\mathrm{E}$ \\
\hline $\mathrm{E}$ & $\mathrm{K}$ \\
\hline $\mathrm{C}, \mathrm{E}, \mathrm{K}$ & $\mathrm{C}, \mathrm{K}$ \\
\hline E, Fya, Jkb & $\mathrm{K}$ \\
\hline K, E, Dia & Lea, Leb, I \\
\hline C, E, K & WA \\
\hline $\mathrm{E}, \mathrm{K}$ & $\mathrm{D}, \mathrm{E}$ \\
\hline $\mathrm{E}$ & $\mathrm{E}, \mathrm{K}$ \\
\hline K & $\mathrm{D}, \mathrm{E}, \mathrm{C}, \mathrm{K}$ \\
\hline $\mathrm{e}$ & $\mathrm{E}, \mathrm{K}$ \\
\hline $\mathrm{E}$ & C, E, Jsa, V \\
\hline $\mathrm{K}$ & $\mathrm{K}, \mathrm{JsA}, \mathrm{GoA}, \mathrm{V}, \mathrm{Cw}$ \\
\hline $\mathrm{K}$ & $\mathrm{K}$ \\
\hline C, S, E, K & E, Kpa,K \\
\hline K & $\mathrm{K}$ \\
\hline E, S, HRB & C, E, S, hr-b \\
\hline E, K, LeA & $\mathrm{C}, \mathrm{E}$ \\
\hline K, E, LeA, & $\mathrm{K}, \mathrm{E}$ \\
\hline M & $\mathrm{E}$ \\
\hline $\mathrm{E}$ & C, E, K, Кра \\
\hline $\mathrm{C}$ & E, C, M, D, Fya \\
\hline $\mathrm{C}, \mathrm{K}$ & K, Fya \\
\hline C, E, K, Fya & E, K, Jsa, Cob, Wra \\
\hline E, K, FYA, S, V & $\begin{array}{l}\text { C, D, E, S, FyA, Jkb, Jsa, } \\
\text { K, V }\end{array}$ \\
\hline $\mathrm{E}$ & $\mathrm{K}$ \\
\hline $\mathrm{E}$ & $\mathrm{E}$ \\
\hline E, S, FyA, JkB, K, LeA & $\mathrm{S}, \mathrm{JkB}, \mathrm{E}, \mathrm{I}$ \\
\hline
\end{tabular}

alloimmunization with male gender, old age and mean number of red cell units transfused [6].

Similar to several other studies, majority of the alloantibodies in this study were against the $\mathrm{Rh}$ and Kell antigens [8, 9]. Antigen matching to the D, C, E, and Kell antigens in all patients undergoing chronic red cell exchange was shown to reduce the risk of alloimmunization and is considered standard of care in several institutions. However, literature is conflicting on the role of prophylactic antigen matching and a recent 
Table 4: Association of variables with development of alloimmunization

\begin{tabular}{llll}
\hline Variable & $\begin{array}{l}\text { Patients with } \\
\text { no antibody } \\
\text { (n=53) }\end{array}$ & $\begin{array}{l}\text { Patients } \\
\text { with } \\
\text { antibody } \\
\text { (n=68) }\end{array}$ & p-value \\
\hline $\begin{array}{l}\text { Age } \\
\text { (median) }\end{array}$ & $33(22-64)$ & $30(19-70)$ & 0.105 \\
Units & $455(14-1320)$ & $426(18-1774)$ & 0.604 \\
transfused & & & \\
(median) & & & 0.75 \\
Gender & & $38(0.56)$ & \\
Female & $32(0.60)$ & $30(0.44)$ & \\
Male & $21(0.40)$ & $66(0.97)$ & \\
Genotype & & $2(0.03)$ & \\
SS & $49(0.92)$ & & 0.403 \\
SC & $4(0.08)$ & $18(0.26)$ & \\
ABO & & $8(0.12)$ & \\
A & $21(0.40)$ & $2(0.03)$ & \\
B & $9(0.17)$ & $40(0.59)$ & \\
AB & $2(0.04)$ & & \\
O & $21(0.40)$ & & \\
\hline
\end{tabular}

study by Kacker et al. showed much higher cost for prospective antigen matching compared to history based matching and argues against the clinical benefit of such practice [10]. On the other hand, alloimmunization was still detected after transfusion of $\mathrm{Rh}$ and racially matched units indicating the role of phenotypically variant alleles that can only be detected with genetic testing $[5,6]$.

Interest is developing on the role of blood group genotyping in transfusion services which uses DNA to predict antigens expressed on red cells with high degree of certainty. It will help reduce the cost and time for random serologic testing by making it easier to search for antigen negative units. However, blood group genotyping techniques are not yet FDA approved and remain to be studied and incorporated in clinical practice. (Mark Yazer, MD. Clinical Lab products; Q\&A on the benefits of Blood Group Genotyping on Specialty populations; October 8, 2013).

Pilot programs incorporating blood group genotyping followed by large scale interventional studies will need to be conducted to address the ever increasing cost of alloimmunization in chronically transfused patients [11, 12].

The cost of finding antigen negative units for patients with alloantibodies is tremendous and was found in one study to range from $\$ 135$ to $\$ 500$ based on the number of antigens required to be negative in each unit. The same study showed that establishing institutional inventory of antigen negative units significantly reduced cost as compared to obtaining antigen negative units from outside suppliers, a practice that can be adopted by large transfusion centers [13].

Considering the cost and time needed to provide compatible units to alloimmunized patients with SCD who are on chronic red cell transfusion, the need for interventional studies aimed at understanding and preventing this complication is tremendous [1].

\section{CONCLUSION}

Despite the retrospective nature as well as possibility of missed data for patients who might be transfused elsewhere, the study showed high rate of alloimmunization for patients with SCD on chronic red cell exchange transfusion. Further interventional studies are needed to better understand and reduce development of alloantibodies through improved communication, education and research. The role of genotypic matching in patients on long-term transfusion should also be explored further. There is also a need for consensus guidelines on the clinical as well as cost effectiveness of transfusing phenotypically matched red cell units particularly to the common Rh (E, C) and Kell antigens.

\section{Acknowledgments}

We would like to thank the Detroit Medical Center research review committee, the Karmanos Cancer Center PMRC committee as well as the Institutional Review Board of Wayne State University for giving ethical clearance and approval for the study.

\section{Author Contributions}

Woldie I. - Substantial contributions to conception and design, Acquisition of data, Analysis and interpretation of data, Drafting the article, Revising it critically for important intellectual content, Final approval of the version to be published

Swerdlow P. - Analysis and interpretation of data, Revising it critically for important intellectual content, Final approval of the version to be published

Bluth M.H. - Analysis and interpretation of data, Revising it critically for important intellectual content, Final approval of the version to be published

Mohammad U. - Analysis and interpretation of data, Revising it critically for important intellectual content, Final approval of the version to be published

Landolfi E. - Analysis and interpretation of data, Revising it critically for important intellectual content, Final approval of the version to be published

Chaudrhy S. - Analysis and interpretation of data, Revising it critically for important intellectual content, Final approval of the version to be published

Dyson G. - Analysis and interpretation of data, Revising it critically for important intellectual content, Final approval of the version to be published

O' Malley B.A. - Analysis and interpretation of data, Revising it critically for important intellectual content, Final approval of the version to be published 


\section{Guarantor}

The corresponding author is the guarantor of submission.

\section{Conflict of Interest}

Authors declare no conflict of interest.

\section{Copyright}

(C) 2015 Woldie I. et al. This article is distributed under the terms of Creative Commons Attribution License which permits unrestricted use, distribution and reproduction in any medium provided the original author(s) and original publisher are properly credited. Please see the copyright policy on the journal website for more information.

\section{REFERENCES}

1. MatteocciA, Pierelli L. Redblood cellalloimmunization in sickle cell disease and in thalassaemia: current status, future perspectives and potential role of molecular typing. Vox Sang 2014 Apr;106(3):197208.

2. Natukunda B, Schonewille H, Ndugwa C, Brand A. Red blood cell alloimmunization in sickle cell disease patients in Uganda. Transfusion 2010 Jan;50(1):205 .

3. Badjie KS, Tauscher CD, van Buskirk CM, et al. Red blood cell phenotype matching for various ethnic groups. Immunohematology 2011;27(1):12-9.

4. Bao $\mathrm{W}$, Zhong $\mathrm{H}, \mathrm{Li} \mathrm{X}$, et al. Immune regulation in chronically transfused allo-antibody responder and nonresponder patients with sickle cell disease and beta-thalassemia major. Am J Hematol 2011 Dec;86(12):1001-6.

5. Vichinsky EP. The prevention and management of alloimmunization in sickle cell disease: The benefit of extended phenotypic matching of red blood cells. Immunohematology 2012;28(1):20-3.
6. Chou ST, Jackson T, Vege S, Smith-Whitley K, Friedman DF, Westhoff CM. High prevalence of red blood cell alloimmunization in sickle cell disease despite transfusion from Rh-matched minority donors. Blood 2013 Aug 8;122(6):1062-71.

7. Venkateswaran L, Teruya J, Bustillos C, Mahoney D Jr, Mueller BU. Red cell exchange does not appear to increase the rate of allo- and auto-immunization in chronically transfused children with sickle cell disease. Pediatr Blood Cancer 2011 Aug;57(2):294-6.

8. Miller ST, Kim HY, Weiner DL, et al. Red blood cell alloimmunization in sickle cell disease: Prevalence in 2010. Transfusion 2013 Apr;53(4):704-9.

9. Mijovic A, Perera IG, Thein SL. Red blood cell alloimmunization in sickle cell disease-prevalence and trends: A single-center cross-sectional study from United Kingdom. Transfusion 2013 Dec;53(12):327980.

10. Kacker S, Ness PM, Savage WJ, et al. Costeffectiveness of prospective red blood cell antigen matching to prevent alloimmunization among sickle cell patients. Transfusion 2014 Jan;54(1):86-97.

11. Storry JR, Olsson ML. Will Genotyping Replace Serology in Future Routine Blood Grouping? Opinion 4: Personalized versus Universal Blood Transfusions - Combining the Efforts. Transfus Med Hemother 2009;36(3):232-3.

12. Legler TJ, Eber SW, Lakomek M, et al. Application of RHD and RHCE genotyping for correct blood group determination in chronically transfused patients. Transfusion 1999 Aug;39(8):852-5.

13. Le N, Harach ME, Kay JK, Brown RP, Everetts JN, Herman JH. Establishing an antigen-negative red blood cell inventory in a hospital-based blood bank. Transfusion 2014 Feb;54(2):285-8.
Access full text article on other devices

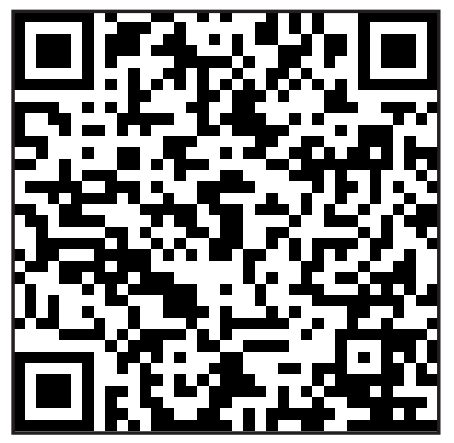

Access PDF of article on other devices

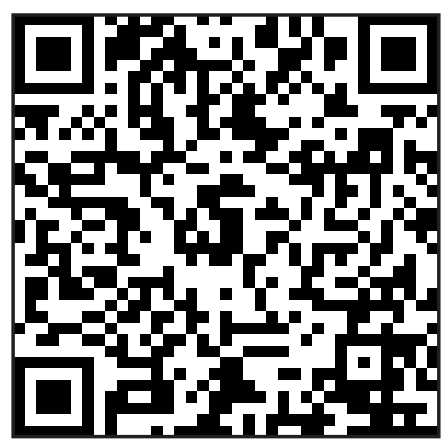

